\title{
Effect of dietary tryptophan on muscle, liver and whole-body protein synthesis in weaned piglets: relationship to plasma insulin
}

\author{
BY N. O. CORTAMIRA*, B. SEVE†, Y. LEBRETON AND P. GANIER \\ INRA, Station de Recherches Porcines, Saint-Gilles, 35590 L'Hermitage, France
}

(Received 19 December 1990 - Accepted 25 February 1991)

\begin{abstract}
Two experiments were carried out with piglets, $3-5 \mathrm{~kg}$ live weight, to evaluate the effects of feeding a tryptophan (TRP)-deficient diet for 2 weeks on protein synthesis rates measured in vivo $2 \mathrm{~h}$ after a meal. In the first experiment on twenty piglets fed on $250 \mathrm{~g}$ protein $/ \mathrm{kg}$ diets, TRP deficiency $(0.77 \mathrm{~g} / 16 \mathrm{~g}$ nitrogen) as compared with adequacy $(1.17 \mathrm{~g} / 16 \mathrm{~g} \mathrm{~N})$ significantly decreased feed intake, growth performance and fractional protein synthesis rates (FSR), without variation of RNA in longissimus dorsi (LD) and with parallel increases in RNA in semitendinosus (ST) muscle and liver. In the second experiment thirty-two piglets were tube-fed deficient and adequate diets at the two feeding levels (LF) previously achieved. Both TRP and LF significantly increased growth performance and FSR, but not RNA, in LD and ST muscle, with a trend to a synergy between the two factors (TRP $\times$ LF interaction). In another muscle, trapezius (TR), the same interaction was only apparent in RNA content. Among the three muscles it was in LD that FSR was the most responsive to dietary TRP (significant muscle $\times$ TRP interaction). In the liver the TRP $\times$ LF interaction on FSR and not RNA was the major significant effect, indicating that higher TRP and higher LF were both required to get the maximum protein synthesis rate. At 30 min after a meal the same significant interaction effect was shown on plasma glucose, whilst the higher LF increased plasma insulin with both diets. After a further 30 min the appearance of a similar significant effect of the TRP $\times$ LF interaction on plasma insulin resulted from its abatement when the deficient diet had been fed at high LF. These results suggest that dietary TRP deficiency decreased muscle and liver protein synthesis rates in relation to a decrease in the post-prandial release of insulin following a decreased rate of nutrient absorption.
\end{abstract}

Tryptophan: Protein synthesis: Insulin: Pig

Protein metabolism is controlled by nutritional state and is known to be very sensitive to short-term variations in energy or protein supply, or both (Clugston \& Garlick, 1982). Muscle protein synthesis response to the meal was shown to be closely related to plasma insulin concentrations in growing animals (Garlick \& Lobley, 1987). Longer-term influences of energy intake and diet composition were particularly investigated in growing pigs. Increase in energy intake was shown to improve nitrogen retention as a result of increments in both protein synthesis and degradation (Reeds et al. 1980). The same observation was made when purified protein was added to a protein-deficient diet (Reeds et al. 1981).

Increase in growth performance, or nitrogen retention, may also be achieved through improved protein quality. This is usually obtained by supplementing the diet with the limiting amino acid and will decrease protein requirement for a given level of protein deposition. More generally, adjusting supplies of essential amino acids to an 'ideal protein' pattern (Wang \& Fuller, 1989) should be the only way to express thoroughly the growth potential of pigs, allowing them to maximize feed intake (Henry, 1988). Whether these

* Present address: INTA Porcine Section, EEA, 2700 Pergamino, Argentine.

$\dagger$ For reprints. 
improvements in performance are achieved through increased protein synthesis rates is still controversial. Lysine addition to a deficient diet was shown to decrease amino acid oxidation without great effect on protein turnover (Fuller et al. 1987) or with accelerations in both synthesis and degradation of body protein (Salter et al. 1990). These authors used 'tracer-dose' methods, in which the assumed precursor pool and the extent of recycling of the label may be questioned. Moreover, in their studies direct values were available only for whole-body amino acid fluxes. For these reasons, in a series of experiments designed to investigate the effect of amino acid balance on protein synthesis it was decided to use the 'flooding-dose' technique, which ensures a homogeneous labelling of the precursor pools throughout the body (McNurlan et al. 1979; Garlick et al. 1980) and involves direct measures of the incorporation of label into protein, giving values for each organ or tissue as well as the whole body (Attaix et al. 1988).

Use of the young pig as a model in studies of the response of protein synthesis to amino acid supply is of particular interest because, in the conditions of energy undernutrition and stress associated with weaning, dietary protein quantity and quality were shown to be determining factors in the resumption of growth (Sève, 1985). Among essential amino acids tryptophan (TRP) is certainly one of the most critical at weaning in the effect of its deficiency on the appetite of piglets (Sève et al. 1978) in the same way as of older pigs (Montgomery et al. 1980). Indirect evidence of a depressive effect of TRP deficiency on protein synthesis rates was obtained in tissues of several species (Sidransky et al. 1971; Majumdar, 1979) including pig muscle (Lin et al. 1988). However, the effect on true rates of protein synthesis in vivo has not been reported in pig or in other species. The present study shows initially that in ad lib.-fed piglets chronic TRP deficiency markedly reduces protein synthesis rates. In a second experiment designed to dissociate the effect of energy intake from that of amino acid balance it is shown that additional energy intake of a deficient diet cannot re-establish protein synthesis rates at the control level. The relationship with plasma insulin response to each meal is also examined.

\section{MATERIALS AND METHODS}

\section{Animals and diets}

Pigs of the Large White breed were available from the herd of INRA-St-Gilles. Two experiments (Expt 1 and Expt 2) were conducted for 2 weeks from weaning at $10 \mathrm{~d}$ of age (day 0). Blocks of two (Expt 1) or four (Expt 2) pigs were selected within litters on a live weight basis. Animals within the same block were reared in adjoining individual pens on wired floors at $30^{\circ}$. Half of them were fed on the basal deficient diet $(t)$; see Table 1 . The other half were fed on the same diet supplemented with purified L-TRP $(T)$; Table 1. TRP contents were 0.77 and $1.17 \mathrm{~g} / 16 \mathrm{~g} \mathrm{~N}$ respectively.

\section{Feeding methods}

In Expt 1 piglets were offered pelleted diets $(2.5 \mathrm{~mm})$ according to the feeding plan shown in Table 2, which was designed to be slightly higher than the usual spontaneous feed intake of such pigs. Water was available ad lib.

In Expt 2 each diet was force-fed at two levels $(2 \times 2$ factorial design). Each factorial combination was randomly allocated within each block. The first level of feeding $(l)$ matched the overall average intake of the deficient diet $(t)$ in Expt 1, i.e. $800 \mathrm{~g}$ dry matter $(D M) / 2$ weeks. The second level $(L)$ was the average intake of diet $T$ in Expt 1, i.e. $1100 \mathrm{~g}$ $\mathrm{DM} / 2$ weeks. Force-feeding was performed by mixing the feed with water, to a final DM content of $230 \mathrm{~g} / \mathrm{kg}$ and dosing via an oesophageal catheter into the stomach (see surgical methods, p. 425) with a syringe. Daily allowances of the mixture are reported in Table 2. 
Table 1. Composition of experimental diets

\begin{tabular}{|c|c|c|}
\hline & TRP-deficient & TRP-adequate \\
\hline \multicolumn{3}{|l|}{ Dietary components $(\mathrm{g} / \mathrm{kg})$} \\
\hline Dried skimmed milk & $150 \cdot 0$ & $150 \cdot 0$ \\
\hline CPSP $90^{*}$ & $126 \cdot 0$ & $126 \cdot 0$ \\
\hline Maize-gluten meal $60 \dagger$ & $160 \cdot 0$ & $160 \cdot 0$ \\
\hline Maize starch $\dagger$ & 384.9 & 383.9 \\
\hline Maize oil & $110 \cdot 0$ & $110 \cdot 0$ \\
\hline Dicalcium phosphate & $46 \cdot 0$ & 460 \\
\hline Calcium carbonate & $8 \cdot 0$ & $8 \cdot 0$ \\
\hline Sodium chloride & $1 \cdot 0$ & $1 \cdot 0$ \\
\hline L-lysine hydrochloride & $4 \cdot 1$ & $4 \cdot 1$ \\
\hline L-tryptophan (TRP) & - & $1 \cdot 0$ \\
\hline Vitamin and mineral premix + & $10 \cdot 0$ & $10 \cdot 0$ \\
\hline \multicolumn{3}{|l|}{ Chemical analysis (g/kg) } \\
\hline Dry matter & $927 \cdot 5$ & $915 \cdot 1$ \\
\hline Nitrogen $\times 6.25$ & $250 \cdot 6$ & $249 \cdot 6$ \\
\hline Ash & $81 \cdot 7$ & $77 \cdot 6$ \\
\hline TRP\& & 1.9 & $2 \cdot 9$ \\
\hline
\end{tabular}

* Solubilized fish-protein concentrate; Sopropêche, Boulogne sur Mer, France.

$\dagger$ From Roquette Frères, Lestrem, France.

$\$$ Contained $(\mathrm{mg} / \mathrm{kg}): \mathrm{Fe} 100, \mathrm{Zn} 100, \mathrm{Cu} 20, \mathrm{Mn} 40, \mathrm{Co} 2, \mathrm{I}$ 1, retinol 3, cholecalciferol 005, $\alpha$-tocopherol acetate 20 , phytylmenoquinone 1 , thiamin 2 , riboflavin 10 , calcium pantothenate 20 , pyridoxine 10 , niacin 30 , ascorbic acid 40 , biotin ( $1 \%$ ) 0.2 , cyanocobalamin 0.05 , choline 800 and carbadox 50 .

$\$$ Calculated from tables of feed composition (INRA, 1989).

\section{Surgical methods}

Expt 1. Each piglet underwent a single surgical operation on day 0 (Table 2). A silicon catheter (internal diameter $0.76 \mathrm{~mm}$, external diameter $1.65 \mathrm{~mm}$ ) was fitted into the jugular vein, from the auricular vein. This catheter was used for injections and blood sampling.

Expt 2. Each piglet underwent two operations on day 0 and 10 . On day 0 a polyurethane catheter (external diameter $4.75 \mathrm{~mm}$, internal diameter $4.00 \mathrm{~mm}$ ) was fitted into the stomach via the oesophagus through an incision in the neck. Thus the catheter directly entered the pharynx and was protected from the teeth of the pig. In this way the animal could still drink water or eat feed without hindrance. The catheter was taken outside the cage with a counterweight in such a way that the pig was relatively unrestrained and could be easily fed without disturbance. The second operation on day 10 was as described for Expt 1 .

\section{Experimental procedures at slaughter}

Pigs from the same blocks were individually slaughtered at $0.5 \mathrm{~h}$ intervals during the morning of day 15. After an overnight fast they had their last meal at zero time, $2 \mathrm{~h}$ before protein synthesis measurements. Blood samples were taken from the jugular catheter in the fasted state (zero time), at 30 and $60 \mathrm{~min}$ after feeding and at slaughter (132 min after feeding). At $12 \mathrm{~min}$ before slaughter (120 min after feeding) pigs were dosed through the same catheter with $5.5 \mathrm{ml} 150 \mathrm{mM}$-L-phenylalanine $/ \mathrm{kg}$ live weight combined with $300 \mathrm{KBq}$ $\mathrm{L}-\left(4-{ }^{3} \mathrm{H}\right)$ phenylalanine (CEA, France) $/ \mathrm{ml}$ in Expt 1 and $600 \mathrm{KBq} / \mathrm{ml}$ in Expt 2. Pigs were slaughtered after anaesthesia by cutting the carotid arteries. Samples of liver, longissimus dorsi (LD), semitendinosus (ST) and trapezius (TR, in Expt 2 only) muscles were immediately removed and deep-frozen in liquid $\mathrm{N}_{2}$. The time-period elapsed since the injection was recorded. In Expt 2, the contents of the digestive tract were discarded and the 
Table 2. Expts 1 and 2. Daily feed allowances*

\begin{tabular}{|c|c|c|c|c|}
\hline \multirow[b]{2}{*}{ Age (d) } & \multirow{2}{*}{$\begin{array}{c}\text { Day of } \\
\text { experiment }\end{array}$} & \multirow[b]{2}{*}{$\operatorname{Expt} \iota^{\dagger}$} & \multicolumn{2}{|c|}{ Expt $2 \ddagger$} \\
\hline & & & High LF & Low LF \\
\hline 10 & 0 & 40 & 60 & 60 \\
\hline 11 & 1 & 40 & 120 & 120 \\
\hline 12 & 2 & 50 & 180 & 120 \\
\hline 13 & 3 & 50 & 240 & 180 \\
\hline 14 & 4 & 60 & 240 & 180 \\
\hline 15 & 5 & 70 & 300 & 225 \\
\hline 16 & 6 & 80 & 300 & 225 \\
\hline 17 & 7 & 95 & 360 & 270 \\
\hline 18 & 8 & 110 & 420 & 315 \\
\hline 19 & 9 & 125 & 420 & 315 \\
\hline 20 & 10 & 140 & $320 \AA$ & $240 \S$ \\
\hline 21 & 11 & 155 & $540^{\circ}$ & $405^{\circ}$ \\
\hline 22 & 12 & 170 & 540 & 405 \\
\hline 23 & 13 & 180 & 540 & 405 \\
\hline 24 & $14 \|$ & 90 & 240 & 180 \\
\hline
\end{tabular}

LF, feeding level.

* Offered amounts, not taking into account refusals (Expt 1) or experimental errors in dosing (Expt 2).

$\dagger$ Grams of pelleted diet/d in two meals.

$\$$ Millilitres mixture of $25 \mathrm{~g}$ air-dry feed made up to $100 \mathrm{~g}$ with water (i.e. $230 \mathrm{~g}$ final dry matter $/ \mathrm{kg}$ ) in three tube-fed meals $/ \mathrm{d}$. The density of the mixture was about $1 \cdot 1 \mathrm{~g} / \mathrm{ml}$.

$\S$ Day of surgical operation; the morning meal was not fed.

$\|$ The morning meal was given $2 \mathrm{~h}$ before phenylalanine injection on slaughter day. For half the replications in Expt 2 slaughter day was day 15, and pigs were fed on day 14 as on day 13.

rest of the whole empty body without blood was also frozen in liquid $\mathrm{N}_{2}$. It was later ground and sampled, after mechanical homogenization, in order to determine protein synthesis in the whole body as well as in the individual tissues.

\section{Measurements of fractional protein synthesis rates}

Fraction rates of protein synthesis could be calculated after determination of the phenylalanine-specific radioactivities in the free pools (SA) and in the tissue protein (SB) as $K_{S}=100(\mathrm{SB} / \mathrm{SA}) / t$, where $t$ is the time-period post-injection, according to procedures described by Garlick et al. (1980). This calculation involved an approximation, since it was assumed that SA measured at slaughter did not significantly differ from the average value during the total incorporation time of labelled phenylalanine into tissue protein (Kelly \& Goldspink, 1982; Preedy \& Garlick, 1985; Sève et al. 1986).

\section{Insulin and glucose determination}

Plasma insulin was measured by a radioimmunological technique (Berson \& Yalow, 1959). Guinea-pig antibodies (Laboratoires Miles, France) and monocomponent insulin (Novo Research Institute, Denmark) were used. Lower and upper limits of validity were 5 and 250 units $/ \mathrm{ml}$ respectively. Plasma glucose was determined by the glucose-oxidase $(E C 1.1 .3 .4)$ technique (Biomérieux, France).

\section{Statistical procedures}

Litter, TRP and LF effects were tested by analysis of variance using the SAS general linear model procedures (GLM; SAS Institute Inc, 1989). Results presented in Tables 3-6 are least-square-adjusted means with residual standard deviations (RSD). In order to test the 
Table 3. Expts I and 2. Effect of dietary tryptophan (TRP) and level of feeding on growth rate and feed intake and feed efficiency in pigsł

\begin{tabular}{|c|c|c|c|c|c|c|}
\hline \multirow{2}{*}{$\begin{array}{l}\text { Dietary TRP }(\mathrm{g} / \mathrm{kg}) \ldots \\
\text { Level of feeding } \$ \ldots\end{array}$} & \multicolumn{2}{|c|}{1.9} & \multicolumn{2}{|c|}{$2 \cdot 9$} & \multicolumn{2}{|c|}{ Statistical significance } \\
\hline & Low & High & Low & High & RSD & Effects \\
\hline \multicolumn{7}{|l|}{ Expt 1} \\
\hline Daily wt gain $(\mathrm{g} / \mathrm{d})$ & 15 & - & - & 61 & $14 \cdot 4$ & $\mathrm{~T}^{* *}$ \\
\hline Daily feed intake $(\mathrm{g} / \mathrm{d})$ & 55 & - & - & 75 & $9 \cdot 7$ & $\mathrm{~T}^{* *}$ \\
\hline Feed efficiency $(\mathrm{g} / \mathrm{g})$ & 0.22 & - & - & 0.80 & 0.23 & $\mathrm{~T}^{* *}$ \\
\hline \multicolumn{7}{|l|}{ Expt 2} \\
\hline Daily weight gain $(\mathrm{g} / \mathrm{d})$ & 48 & 73 & 50 & 84 & $6 \cdot 2$ & $\mathrm{~T}^{*} \mathrm{LF}^{*} \mathrm{~T} \times \mathrm{LF} \dagger$ \\
\hline Daily feed intake $(\mathrm{g} / \mathrm{d})$ & 61 & 81 & 61 & 81 & $1 \cdot 6$ & $L F^{* *}$ \\
\hline Feed efficiency $(\mathrm{g} / \mathrm{g})$ & 0.78 & 0.90 & 0.81 & 1.03 & 0.09 & $\mathrm{~T}^{*} \mathrm{LF}^{* *}$ \\
\hline
\end{tabular}

RSD, residual standard deviation ( $9 \mathrm{df}$ in Expt 1, $21 \mathrm{df}$ in Expt 2; means for ten pigs in Expt 1 and eight pigs in Expt 2). T, effect of TRP; LF, effect of level of feeding; $\mathrm{T} \times \mathrm{LF}$, effect of interaction: $+P<0 \cdot 10,{ }^{*} P<0 \cdot 05$, ** $P<0.01$.

‡ Calculation of performances did not include slaughter day. Feed intake and efficiency were expressed on a dry matter basis.

\$ In Expt 1, low and high levels of feeding corresponded to spontaneous feed intake controlled by weighing the refusals. In Expt 2, low and high levels of feeding were obtained by tube-feeding the amounts presented in Table 2 , with some adjustments to individual tolerance of pigs and control by weight of syringe doses. For details of diets and treatments see p. 424 and Table 1.

effects of tissue or time of sampling and their interactions with the factors under study, the data were also analysed as from a 'split-plot' design (Cochran \& Cox, 1957) by the 'repeated' measures statement available in the SAS GLM procedure. Main plots were the entire animals over the whole experimental period. Sub-plots were either different muscles or times of blood sampling within the same pig. Main effects, litter, TRP and LF, were tested using the residual variation between animals as error. Sub-plot effects and their interactions with the main effects were tested using the residual within-animal variation as error. Simple contrast transformation as available within the repeated statement was used to compare responses with treatments between muscles. Polynomial orthogonal contrast transformation was used to compare response curves of plasma data between dietary treatments. Plasma insulin values were converted into logarithms before analysis (Garlick et al. 1983). Finally, correlations independent of litter and diet effects were calculated between plasma insulin concentrations at different times of sampling and protein synthesis data using the multivariate analysis of variance 'Anvarm' from the AMANCE statistical package (Bachacou et al. 1981).

\section{RESULTS}

\section{Growth and feed efficiency}

Daily weight gain was significantly depressed by TRP deficiency. In Expt 1 the decrease was very sharp $(75 \%, P=0.0001)$ and only partly explained by the reduction $(27 \%, P=$ 0.0001 ) in dry intake (Table 3). In Expt 2 the difference between dietary groups $t l$ and $T L$, involving the effect of the two factors TRP and LF and thus comparable with that in Expt 1 , was not so great $(43 \%)$. In fact, TRP deficiency mainly affected weight gain of pigs on the higher level of feeding $(15 \%)$, as was reflected in a TRP $\times$ LF interaction approaching significance $(P=0.0586)$. The average reduction in weight gain due to feed restriction was much higher $(37 \%, P=0.0001)$. In both experiments, variations in feed efficiency paralleled those in weight gain. 
Table 4. Expts 1 and 2. Effect of dietary tryptophan (TRP) and level of feeding on fractional rates of protein synthesis in pigs

\begin{tabular}{|c|c|c|c|c|c|c|}
\hline \multirow{2}{*}{$\begin{array}{l}\text { TRP } \mathrm{g} / \mathrm{kg} \ldots \\
\text { Level of feedingt... }\end{array}$} & \multicolumn{2}{|c|}{1.9} & \multicolumn{2}{|c|}{$2 \cdot 9$} & \multicolumn{2}{|c|}{ Statistical significance } \\
\hline & Low & High & Low & High & $\mathrm{RSD}$ & Effects \\
\hline \multicolumn{7}{|l|}{ Expt 1} \\
\hline Liver & 80 & 一 & - & 89 & $9 \cdot 6$ & $\mathrm{~T}+$ \\
\hline \multicolumn{7}{|l|}{ Muscle } \\
\hline LD & $8 \cdot 2$ & - & - & 11.9 & $2 \cdot 7$ & $\mathrm{~T}^{*}$ \\
\hline ST & $7 \cdot 7$ & - & - & $10 \cdot 0$ & $2 \cdot 1$ & $\mathrm{~T}^{*}$ \\
\hline \multicolumn{7}{|l|}{ Expt 2} \\
\hline Liver & 73 & 72 & 76 & 90 & $8 \cdot 2$ & $\mathrm{~T}^{* *} \mathrm{LF}^{*} \mathrm{~T} \times \mathrm{LF}^{*}$ \\
\hline \multicolumn{7}{|l|}{ Muscle } \\
\hline LD & 8.5 & 8.9 & $9 \cdot 8$ & $11 \cdot 7$ & $1 \cdot 3$ & $\mathrm{~T}^{*} \mathrm{LF}^{*} \mathrm{~T} \times \mathrm{LF}^{\dagger}$ \\
\hline ST & $7 \cdot 5$ & 7.9 & $7 \cdot 9$ & $9 \cdot 8$ & $1 \cdot 2$ & $T^{*} L_{F}^{* *} T \times L F \dagger$ \\
\hline TR & $7 \cdot 1$ & $7 \cdot 7$ & $7 \cdot 5$ & $8 \cdot 9$ & $1 \cdot 2$ & $\mathrm{~T} \dagger \mathrm{LF}^{*}$ \\
\hline Whole body & $12 \cdot 3$ & $12 \cdot 7$ & $12 \cdot 8$ & 14.9 & $1 \cdot 2$ & $\mathrm{~T}^{* *} \mathrm{LF}^{*} \mathrm{~T} \times \mathrm{LF}^{\dagger}$ \\
\hline
\end{tabular}

LD, longissimus dorsi; ST, semitendinosus; TR, trapezius. RSD, residual standard deviation (9 df in Expt 1 , $2 \mathrm{Idf}$ in Expt 2; means for ten pigs in Expt 1 and eight pigs in Expt 2). T, effect of TRP; LF, effect of level of feeding; $\mathrm{T} \times \mathrm{LF}$, effect of interaction: $\uparrow P<0 \cdot 10,{ }^{*} P<0 \cdot 05, * * P<0 \cdot 01$.

$\ddagger$ In Expt 1 , low and high levels of feeding corresponded to spontaneous feed intake controlled by weighing the refusals. In Expt 2, low and high levels of feeding were obtained by tube-feeding the amounts presented in Table 2 , with some adjustments to individual tolerance of pigs and control by weight of syringe doses. For details of diets and treatments see p. 424 and Table 1.

\section{Protein synthesis rates}

In Expt 1 there was a trend to an increase in the rate of liver protein synthesis with the addition of TRP to the deficient diet $(P=0.0632)$ (Table 4). In Expt 2 a TRP $\times$ LF interaction was clearly shown $(P=0.0176)$ : the increase in LF did not suppress the effect of TRP deficiency on protein synthesis, and the response to additional TRP required an increase in feed intake.

In Expt 1 the effect of TRP deficiency on protein synthesis rates was more apparent in LD than in ST (TRP $\times$ muscle interaction, $P=0.0358$ ). Protein synthesis rate was significantly lower in ST than in LD $(P=0.0026)$. The average reduction in protein synthesis rate under dietary TRP deficiency was $27 \%(P=0.0205)$. In Expt 2 the effect of TRP $\times$ muscle interaction on protein synthesis rate was also significant $(P=0.0079)$. Evidence that LD was more responsive to additional dietary TRP than the two other muscles $(P=0.0212)$, appeared from the analysis of contrasts. Moreover, in LD the average protein synthesis rate $(9.64 \% / \mathrm{d})$ was significantly higher $(P=0.0001)$ than in ST $(8.38 \% / \mathrm{d})$, which was also different $(P=0.0538)$ from TR $(7.89 \% / \mathrm{d})$. Both additional TRP and feed intake significantly increased rates of muscle protein synthesis, but the TRP effect was more apparent at higher LF, whilst the LF effect was especially observed at higher TRP. The effect of this TRP $\times$ LF interaction approached significance in LD $(P=$ $0.0875)$ and ST $(P=0-0979)$. The effects of the factors under study on the rate of wholebody protein synthesis were similar to those in LD and ST muscles with the same tendency to a TRP $\times$ LF interaction $(P=0.0579)$. Thus, they did not differ greatly from those in the liver.

\section{Tissue RNA}

In Expt 1 the decrease in tissue RNA content due to TRP deficiency never exceeded $10 \%$, although it reached some significance in the liver $(P=0.0922)$ and the ST muscle $(P=$ 0.0011 ), which was more responsive than LD (TRP $\times$ muscle interaction, $P=0.0241$ ) 
(Table 5). Small effects were also apparent in Expt 2, in which there was evidence of a tendency to a TRP $\times$ LF interaction on RNA content in TR $(P=0.0816)$ similar to that described previously on rates of protein synthesis in the other muscles, and to increases in the liver $(P=0.0595)$ and whole-body $(P=0.0685)$ contents in RNA with feed intake.

\section{Protein synthesis per unit RNA (RNA activity)}

In Expt 1 the effect of additional dietary TRP on liver RNA activity was not significant (Table 6). By contrast, in Expt 2 a significant TRP $\times$ LF interaction, similar to those described previously, appeared in the results of RNA activity in the liver $(P=0.0094)$ and, to a lesser extent, in the whole body $(P=0.0650)$.

The effect of the TRP $\times$ muscle interaction on protein synthesis per unit RNA was significant in Expt 1, where LD was more sensitive to the deficiency than ST $(P=0.0134)$. In Expt 2, although this interaction did not reach significance, decreases in RNA activity due to TRP deficiency were more apparent in LD and ST than in TR muscle. This was confirmed by separate statistical analysis of the results for each muscle. In both experiments (Expts 1 and 2) the average RNA activity appeared to be lower in ST than in LD ( $P=0.0171$ and $P=0.0001$ respectively).

In muscles, the effect of the TRP $\times$ LF interaction was not significant whether analysed together or separately. Increases in RNA activity with both higher TRP and LF were significant in LD $(P=0.0084$ for TRP, $P=0.0090$ for LF) and ST $(P=0.0520$ for TRP, $P=0.0507$ for LF), but very small in TR $(P=0.0719$ for LF only).

\section{Plasma glucose and insulin}

TRP and LF effects on plasma glucose and insulin were studied in Expt 2. In fasted animals there was no effect of these factors on plasma glucose. Plasma insulin was too low $(<5$ unit $/ \mathrm{ml})$ to be measured accurately. Figs 1 and 2 show the post-prandial patterns for each combination of the factors TRP and LF. At 30 min a significant effect of the TRP $\times$ LF interaction $(P=0.0312)$, similar to those described previously, could be shown on plasma glucose. Plasma glucose associated with the high TRP, high LF treatment remained high at 60 min, but the significance of the TRP $\times$ LF interaction was less $(P=0.0586)$ than at $30 \mathrm{~min}$ and had disappeared by the time of slaughter. At $30 \mathrm{~min}$ plasma insulin increased with LF $(P=0.0456)$ regardless of TRP. The same interaction effect was observed on plasma insulin at $60 \mathrm{~min}$ only $(P=0.0124)$. This response could also be described in terms of differences between the quadratic terms of the variations with time from 30 to $132 \mathrm{~min}$ ( $P=0.0186$ ), corresponding to the most significant component of the TRP $\times$ LF $\times$ time interaction $(P=0.0864)$ : in Fig. 2 it is clear that the curvature of the variation in the $t L$ group, with an important fall in plasma insulin between 30 and $60 \mathrm{~min}$, was different from that in the three other groups ( $T L, T l$ and $t l)$.

From the results of the overall statistical analysis it could have been concluded that additional TRP induced a significant elevation in average plasma insulin from 68.2 (SE 6.6) to 85.4 (SE 6.4) unit/ml, whilst additional feed intake induced a significant increase from 62.8 (SE 6.5) to 90.9 (SE 6.5) unit/ $\mathrm{ml}$ in the average plasma insulin. However, the trend to a TRP $\times$ LF interaction means that the two factors were more synergistic than additive in their effects on plasma insulin, as shown 60 min after a meal.

By multivariate analysis it was possible to calculate significant correlations, independent of litter or diet, between plasma insulin at $30 \mathrm{~min}$ and muscle protein synthesis rates at 132 min after a meal $(r 0.52, P<0.02$ for LD; $r 0.46, P<0.05$ for ST). These correlations were higher when RNA activity replaced protein synthesis rates $(r 0.64, P<0.01$ for LD; 
Table 5. Expts 1 and 2. Effect of dietary tryptophan (TRP) and level of feeding on tissue contents of RNA ( $\mathrm{mg} / \mathrm{g}$ protein) in pigs

\begin{tabular}{|c|c|c|c|c|c|c|}
\hline \multirow{2}{*}{$\begin{array}{l}\text { TRP } \mathrm{g} / \mathrm{kg} \ldots \\
\text { Level of feeding } \ddagger \text {.. }\end{array}$} & \multicolumn{2}{|c|}{1.9} & \multicolumn{2}{|c|}{$2 \cdot 9$} & \multicolumn{2}{|c|}{ Statistical significance } \\
\hline & Low & High & Low & High & RSD & Effects \\
\hline \multicolumn{7}{|l|}{ Expt 1} \\
\hline Liver & $47 \cdot 9$ & - & - & $50 \cdot 3$ & $2 \cdot 9$ & $\mathrm{~T}+$ \\
\hline \multicolumn{7}{|l|}{ Muscle } \\
\hline LD & 9.9 & - & - & $10 \cdot 5$ & $0 \cdot 80$ & NS \\
\hline ST & $9 \cdot 2$ & - & - & $10 \cdot 3$ & 0.54 & $\mathrm{~T}^{* *}$ \\
\hline \multicolumn{7}{|l|}{ Expt 2} \\
\hline Liver & $42 \cdot 8$ & 45.4 & $44 \cdot 2$ & $44 \cdot 8$ & $2 \cdot 2$ & $\mathrm{LF}^{\dagger}$ \\
\hline \multicolumn{7}{|l|}{ Muscle } \\
\hline LD & $9 \cdot 0$ & $8 \cdot 3$ & $9 \cdot 3$ & $9 \cdot 0$ & 0.9 & NS \\
\hline ST & $10 \cdot 4$ & $10 \cdot 5$ & $10 \cdot 4$ & $11 \cdot 1$ & $0 \cdot 9$ & NS \\
\hline TR & $7 \cdot 7$ & $7 \cdot 4$ & $7 \cdot 5$ & $8 \cdot 4$ & 0.8 & $\mathrm{~T} \times \mathbf{L F}+$ \\
\hline Whole body & $13 \cdot 2$ & $14 \cdot 2$ & $13 \cdot 9$ & $14 \cdot 6$ & $1 \cdot 3$ & $\mathrm{LF} \dagger$ \\
\hline
\end{tabular}

LD, longissimus dorsi; ST, semitendinosus; TR, trapezius. RSD, residual standard deviation ( 9 df in Expt 1 , 21 df in Expt 2; means for ten pigs in Expt 1 and eight pigs in Expt 2); T, effect of TRP; LF, effect of level of feeding; $\mathrm{T} \times \mathrm{LF}$, effect of interaction: NS not significant, $\dagger P<0 \cdot 10, * P<0 \cdot 05, * * P<0.01$.

$\ddagger$ In Expt 1, low and high levels of feeding corresponded to spontaneous feed intake controlled by weighing the refusals. In Expt 2, low and high levels of feeding were obtained by tube-feeding the amounts presented in Table 2 , with some adjustments to individual tolerance of pigs and control by weight of syringe doses. For details of diets and treatments see p. 424 and Table 1.

Table 6. Expts 1 and 2. Effect of dietary tryptophan (TRP) and level of feeding on rates of protein synthesis per unit of RNA ( $\mathrm{g} / \mathrm{g}$ per day) in pigs

\begin{tabular}{|c|c|c|c|c|c|c|}
\hline \multirow{2}{*}{$\begin{array}{l}\text { TRP } \mathrm{g} / \mathrm{kg} \ldots \\
\text { Level of feeding } \neq \ldots\end{array}$} & \multicolumn{2}{|c|}{1.9} & \multicolumn{2}{|c|}{2.9} & \multicolumn{2}{|c|}{ Statistical significance } \\
\hline & Low & High & Low & High & RSI & Effects \\
\hline \multicolumn{7}{|l|}{ Expt 1} \\
\hline Liver & $16 \cdot 7$ & - & - & $17 \cdot 8$ & $2 \cdot 4$ & NS \\
\hline \multicolumn{7}{|l|}{ Muscle } \\
\hline LD & $8 \cdot 5$ & - & - & $11 \cdot 3$ & $2 \cdot 5$ & $\mathrm{~T}^{*}$ \\
\hline $\mathrm{ST}$ & $8 \cdot 5$ & - & - & $9 \cdot 6$ & $2 \cdot 0$ & NS \\
\hline \multicolumn{7}{|l|}{ Expt 2} \\
\hline Liver & $17 \cdot 1$ & $15 \cdot 9$ & $17 \cdot 2$ & $20 \cdot 1$ & $2 \cdot 0$ & $\mathrm{~T} \times \mathrm{LF}^{* *}$ \\
\hline \multicolumn{7}{|l|}{ Muscle } \\
\hline LD & $9 \cdot 5$ & $10 \cdot 7$ & $10 \cdot 8$ & $13 \cdot 1$ & $1 \cdot 7$ & $\mathrm{~T}^{* *} \mathrm{LF}^{* *}$ \\
\hline $\mathrm{ST}$ & $7 \cdot 3$ & $7 \cdot 6$ & 7.6 & $9 \cdot 0$ & $1 \cdot 1$ & $\mathrm{~T}^{*} \mathrm{LF}^{*}$ \\
\hline TR & $9 \cdot 2$ & $10 \cdot 5$ & 9.9 & $10 \cdot 9$ & $1 \cdot 7$ & LFt \\
\hline Whole body & $9 \cdot 5$ & $9 \cdot 0$ & $9 \cdot 4$ & $10 \cdot 4$ & $1 \cdot 1$ & $\mathrm{~T} \times \mathrm{LF} \uparrow$ \\
\hline
\end{tabular}

LD, longissimus dorsi; ST, semitendinosus; TR, trapezius, RSD, residual standard deviation ( 9 df in Expt 1 , $21 \mathrm{df}$ in Expt 2; means for ten pigs in Expt 1 and eight pigs in Expt 2). T, effect of TRP; LF, effect of level of feeding; $\mathrm{T} \times \mathrm{LF}$, effect of interaction: NS, not significant, $\uparrow P<0 \cdot 10,{ }^{*} P<0 \cdot 05,{ }^{*} P<0 \cdot 01$.

$\ddagger$ In Expt 1, low and high levels of feeding corresponded to spontaneous feed intake controlled by weighing the refusals. In Expt 2, low and high levels of feeding were obtained by tube-feeding the amounts presented in Table 2 , with some adjustments to individual tolerance of pigs and control by weight of syringe doses. For details of diets and treatments see p. 424 and Table 1. 


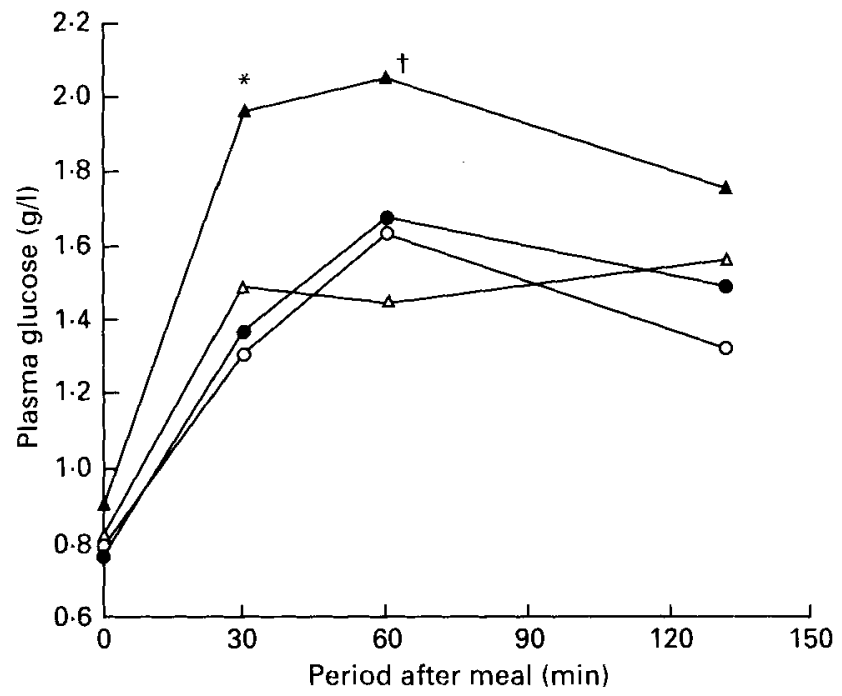

Fig. 1. Effect of dietary tryptophan (TRP) and level of feeding (LF) on post-prandial plasma glucose concentrations. (O), Low TRP, low LF; $(\triangle)$, low TRP, high LF; $(\mathbf{O})$, high TRP, low LF; ( $\mathbf{\Delta})$, high TRP, high LF. For details of diets and treatments, see pp. 424-425 and Tables 1 and 2. ${ }^{*}$ TRP $\times$ LF : $P=0.0312$, RSD 0.26 $(21 \mathrm{df}), \dagger$ TRP $\times$ L.F $: P=0.0586$, RSD $0.41(21 \mathrm{df})$. RSD, residual standard deviation.

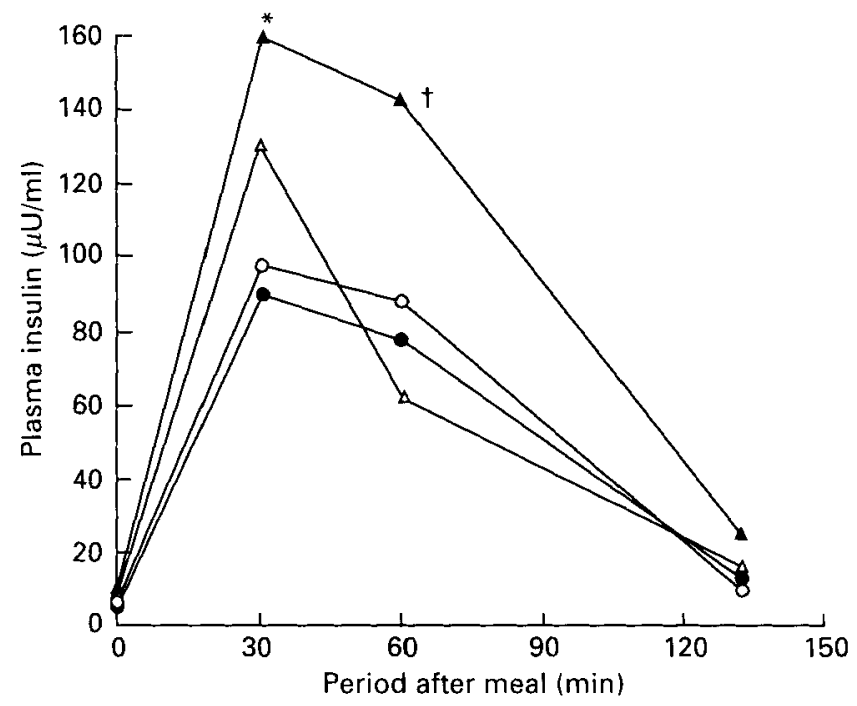

Fig. 2. Effect of dietary tryptophan (TRP) and level of feeding (LF) on post-prandial plasma insulin concentrations. (O), Low TRP, low LF; $(\triangle)$, low TRP, high LF; $(\mathbf{O})$, high TRP, low LF; $(\mathbf{\Delta})$, high TRP, high LF. For details of diets and treatments, see pp. 424425 and Tables 1 and 2. ${ }^{*} \mathrm{LF}: P=0.0456$, RSD 67 (21 df), + TRP $\times$ LF : $P=0 \cdot 0124$, RSD $48(21 \mathrm{df})$. RSD, residual standard deviation. Analysis of the effect of time between 30 and $132 \mathrm{~min}$ : effect of the TRP $\times \mathrm{LF} \times$ time interaction, quadratic component, $P=0.0186$, RSD 28 (21 df). 
$r 0.50, P<0.2$ for ST). They were further increased when variation due to LF, independent of TRP balance, was taken into account $(r 0.72, P<0.01$ for LD; $r 0.60, P$ $<0.01$ for ST).

\section{DISCUSSION}

The response of growth rate to additional TRP was consistent with the results of experiments designed to investigate piglet requirements (Leibholz, 1981; Sève, 1983; Lin et al. 1988). In Expt 1 the $27 \%$ increase in DM intake during the $14 \mathrm{~d}$ following weaning confirmed the highly depressive effect of TRP deficiency on feed intake, as reported many times in pigs (Henry \& Pastuszewska, 1976; Montgomery et al. 1980; Sève et al. 1978; Pérez \& Bourdon, 1982; Lin et al. 1988). Accordingly, it was not possible in the present experiment to dissociate the effect of energy intake from that of amino acid balance. Covariance adjustment of growth rate, to equal feed intake, was not possible without assuming that the response to TRP did not depend on energy intake (no interaction). Then Expt 2 was designed to test this interaction, which proved to approach significance. Tubefeeding allowed two levels of feed intake at each level of dietary TRP to be compared without disturbing the animals and with minimal feed waste. This way, individual variations and experimental errors, as measured by RSD, could be considerably reduced ( 80 , 65 and $55 \%$ decreases in RSD for DM intake, feed efficiency and growth rate respectively). However, it is known that maintenance expenses and heat increment associated with tube feeding can be decreased as compared to energy losses associated with normal feeding (Leblanc et al. 1984). This might be the reason for a higher feed efficiency in Expt 2. Such results were also reported in tube-fed rats (Rothwell \& Stock, 1978).

The injection of a flooding dose of labelled amino acids was used to measure protein synthesis rate in order to minimize errors associated with the identification of the precursor pool (McNurlan et al. 1979). The increase in the injected radioactivity in Expt 2 was probably partly responsible, together with the tube-feeding technique, for the improvement in accuracy of the measurements, particularly in the muscle ( $55 \%$ decrease in RSD). In the liver and ST muscle the results compared fairly well with those previously reported in slightly younger pigs (Sève et al. 1986).

In Expt 1 the trend to an increase in the rate of liver protein synthesis with additional TRP could be explained by the higher RNA content rather than a higher RNA activity. This was in agreement with data on rats (Vesely \& Cihak, 1970), where dietary TRP was shown to enhance RNA synthesis through a stimulation of RNA polymerase I (EC 3.1.27.5) and II (EC 3.1.27.1). On the other hand, Sidransky et al. (1984) reported that an oral load of TRP induced an acceleration of the transfer of mRNA from the nucleus to the cytoplasm, which should have increased RNA activity. This last effect was observed in Expt 2, where a clear difference in rates of liver protein synthesis, between groups comparable with those in Expt 1, could not be related to the variation in RNA content. Although the two experiments involved animals from different litters, which may have been intrinsically dissimilar, an effect of the feeding technique cannot be ruled out as an explanation of this discrepancy. Leblanc et al. (1984) reported a more rapid elevation of plasma insulin in tube-fed than in normally eating young men. This may have been particularly true in piglets, which were tube-fed liquid diets within a time shorter than would be the duration of a normal meal of pellets. According to Jefferson (1980) insulin can promote an acceleration of the rate of liver protein synthesis through an increase in mRNA transcription. This mechanism would be consistent with an increase in RNA activity parallel with an amplification of the insulin response when dietary TRP and feed intake were both elevated.

The choice of the three muscles in the present study was made on the basis of the work 
of Laborde et al. (1985). Longissimus dorsi was taken as representative of a fast-twitch type muscle, characterized by high myofibrillar ATPase (EC 3.6.1.5) and low citrate synthase $(E C 4.3 .1 .7)$ activities. Trapezius represented the opposite slow-twitch type muscle whilst semitendinosus was an intermediate type. However, the present findings were obtained at an early stage of development ( $24 \mathrm{~d}$ of age) when the fibre pattern within each muscle is far from mature. At this stage the proportion of $\beta$ fibres may already differ between the extreme types of muscle but is still quite low in both of them (Lefaucheur et al. 1986). According to Lefaucheur et al. (1986), in the range $1-14 \mathrm{~kg}$ live weight the main difference between LD and muscles nearer to the slow-twitch type would be the much higher allometry of growth in cross-section area of $\alpha \mathrm{R}$ fibres in the former than in the latter. Whether this could explain why the present results opposed findings in rats, according to which protein synthesis rate was higher in slow-twitch type muscles, should be investigated further. On the other hand, the higher responsiveness of a fast-twitch muscle to nutrients would be much more in agreement with what is known about muscle protein metabolism, if it was assumed to be mediated by insulin as proposed by Millward et al. (1983). According to Jefferson (1980), insulin stimulates RNA activity in a fast-twitch muscle whereas it increases the RNA content in a slow-twitch muscle. This is consistent with the results of the present experiment, where the trend to a TRP $\times$ LF interaction on plasma insulin was paralleled by similar trends of protein synthesis rate in LD and RNA content in TR. Lefaucheur et al. (1986) reported that the number of insulin receptors was higher in slow-twitch muscles than in fast-twitch muscles. It is not known whether this is compatible with a higher metabolic response of the latter to large variations in postprandial plasma insulin concentration.

According to our findings there was a chronological distance between variations in plasma insulin concentrations when the highest values were measured, 30 min after the meal, and the correlated ribosomal activity in LD and ST muscles, independent of the effects of dietary factors, at $132 \mathrm{~min}$. This was true also of the similar responses to dietary variations of plasma insulin concentrations $60 \mathrm{~min}$ after feeding, and of liver or muscle protein synthesis more than $1 \mathrm{~h}$ later. The succession of events occurring at tissue or cellular level during this lapse of time should be investigated to determine whether TRP acts through insulin or through another mechanism. Relationships between protein synthesis and plasma insulin have been discussed by Garlick \& Lobley (1987) on the basis of experiments in rats where insulin or glucose was infused intravenously, together with mixtures of amino acids. They stressed the role of branched-chain amino acids in the response of rates of muscle protein synthesis to insulin. The present findings give some support to the hypothesis of the existence of a relationship between protein synthesis in vivo and plasma insulin. They suggest a role for dietary amino acid balance, particularly TRP, in the prolonging of insulin secretion itself from 30 min after a supplemented meal.

The relationship between dietary TRP and insulin response was in agreement with findings on rats (Tsiolakis \& Marks, 1984). However, the TRP $\times$ LF interactions on both plasma glucose and insulin concentrations suggest that additional TRP did not act independently of the increase in feed intake. At $30 \mathrm{~min}$ after a meal, plasma insulin concentration increased with the level of feeding, regardless of TRP supply, probably in response to a first wave of nutrient absorption proportional to total energy intake, rather than to dietary TRP content. At the same time, lower plasma glucose concentration in both groups fed on the low-TRP diet, regardless of the level of feeding, would already reflect a check in the absorption of nutrients related to TRP deficiency. This would explain the rapid decrease in plasma insulin concentration from 30 to $60 \mathrm{~min}$ after feeding diet $t L$. Decrease in plasma insulin concentration has also been discussed in terms of accelerated uptake by membrane receptors (Herrera et al.1981) or catabolism, or both (Grizard et al. 1977, 1980). 
these alternative hypotheses were raised in the context of starvation or severely restricted feeding and not, so far, in the case of amino acid imbalance. Clearly, however, more work is required for a better understanding of the relationship of plasma insulin to dietary TRP.

Fuller et al. (1977) stated that in the pig, as in other species, plasma insulin response is greater when glucose is orally fed rather than when it is infused into the circulating blood. This would suggest that TRP effect was already initiated at the stage of nutrient absorption. According to Tsiolakis \& Marks (1984), on the basis of experiments on rats, this effect would be promoted through secretion of GIP (gastric inhibiting polypeptide, also known as glucose-dependent insulinotropic polypeptide). Whether this secretion is directly stimulated by additional TRP at the level used in the present experiment, or associated with increased nutrient absorption elicited through another mechanism by this small amount of TRP, remains to be established.

\section{REFERENCES}

Attaix, D., Aurousseau, E., Manghebati, A. \& Arnal, M. (1988). Contribution of liver, skin and skeletal muscle to whole-body protein synthesis in the young lamb. British Journal of Nutrition 60, 77-84.

Bachacou, J., Masson, J. P. \& Millier, C. (1981). Manuel de la programmathèque statistique Amance 81. Nancy: Institut National de la Recherche Agronomique.

Berson, S. A. \& Yalow, R. S. (1959). Quantitative aspects of the reaction between insulin and insulin-binding antibody. Journal of Clinical Investigations 38, 1996-2016.

Clugston, G. A. \& Garlick, P. J. (1982). The response of protein and energy metabolism to food intake in lean and obese man. Human Nutrition: Clinical Nutrition 36 C, 57-70.

Cochran, W. G. \& Cox, G. M. (1957). Experimental Designs, 2nd ed. New York, London, Sydney: John Wiley \& Sons, Inc.

Fuller, M. F., Cadenhead, A., Mollison, G. \& Sève, B. (1987). Effects of the amount and quality of dietary protein on nitrogen metabolism and heat production in growing pigs. British Journal of Nutrition 58, 277-285.

Fuller, M. F., Weekes, T. E. C., Cadenhead, A. \& Bruce, J. B. (1977). The protein-sparing effect of carbohydrate. The role of insulin. British Journal of Nutrition 38, 489-496.

Garlick, P. J., Fern, M. \& Preedy, V. R. (1983). The effect of insulin and food intake on muscle protein synthesis in postabortive rats. Biochemical Journal 210, 669-676.

Garlick, P. J. \& Lobley, G. E. (1987). Dietary intake and protein turnover. In Protein Metabolism and Nutrition, European Association for Animal Production Publication no. 35, pp. 18-21 [J. Lehman, editor]. Rostock: Wilhelm-Pieck-Universität.

Garlick, P. J., McNurlan, M. A. \& Preedy, V. R. (1980). A rapid and convenient technique for measuring the rate of protein synthesis in tissues by injection of $\left({ }^{3} \mathrm{H}\right)$ phenylalanine. Biochemical Journal 192, 719-723.

Grizard, J., Arnal, M. \& Pion, R. (1980). Effect of experimental hyperinsulemia on insulin binding in liver plasma membrane. Reproduction Nutrition Développement 20, 311-318.

Grizard, J., Prugnaud, J. \& Pion, R. (1977). Effect of insulin excess on body composition and free amino acid levels in blood. Annales de biologie animale biochimie et biophysique 17, 373-387.

Henry, Y. (1988). Signification de la protéine équilibrée pour le porc: intérêt et limites. (Significance of balanced protein in pigs: advantage and limitations.) INRA Productions Animales 1, 65-74.

Henry, Y. \& Pastuszewska, B. (1976). Conséquences d'une déficience du régime en tryptophane chez le porc sur le niveau d'ingestion et les performances de croissance. (Effect of tryptophan deficiency in the pig diet on feed intake and growth performance.) Annales de Zootechnie 25, 143-148.

Herrera, M. T., Prieto, J. C. \& Goberna, R. (1981). Effect of fasting and refeeding on insulin binding to liver plasma membranes and hepatocytes from normal rats. Hormone and Metabolic Research 13, 441-445.

INRA (1989). L'alimentation des animaux monogastriques, porc, lapin, volailles (The nutrition of simplestomached animals: pig, rabbit, fowi.), 2nd ed. Paris: Institut National de la Recherche Agronomique.

Jefferson, L. S. (1980). Role of insulin in the regulation of protein synthesis. Diabetes 29, 487-496.

Kelly, F. I. \& Goldspink, D. F. (1982). The differing response of four muscle types of dexamethasone treatment in the rat. Biochemical Journal 208, 147-151.

Laborde, D., Talmant, A. \& Moin, G. (1985). Activités enzymatiques métaboliques et contractiles de 30 muscles du porc. Relations avec le $\mathrm{pH}$ ultime atteint après la mort. (Enzyme metabolic and contractile activity in 30 pig muscles and their relationship to ultimate postmortem pH.) Reproduction Nutrition Développement 25, 619-628.

Leblanc, J., Cabanac, M. \& Samson, P. (1984). Reduced postprandial heat production with gavage as compared with meal feeding in human subject. American Journal of Physiology 246, E95-E101.

Lefaucheur, L., Le Peuch, C. \& Vigneron, P. (1986). Characterization of insulin binding to slices of slow- and fasttwitch skeletal muscles in the rabbit. Hormone and Metabolic Research 18, 725-729.

Leibholz, J. (1981). Tryptophan requirements of pigs between 28 and 56 days of age. Australian Journal of Agricultural Research 32, 845-850. 
Lin, F. D., Smith, T. K. \& Bayley, H. S. (1988). A role for tryptophan in regulation of protein synthesis in porcine muscle. Journal of Nutrition 118, 445-449.

McNurlan, M. A., Tomkins, A. M. \& Garlick, P. J. (1979). The effect of starvation on the rate of protein synthesis in rat liver and small intestine. Biochemical Journal 178, 373-379

Majumdar, A. P. N. (1979). Bilateral adrenalectomy: effect of tryptophan on protein synthesis and pepsin activity in the stomach of rats. Scandinavian Journal of Gastroenterology 14, 949-954.

Millward, D. J., Bates, P. C., De Benoist, B., Brown, J. G., Cox, M., Halliday, D., Odedra, B. \& Rennie, M. J. (1983). Protein turnover: the nature of the phenomenon and its physiological regulation. In Protein, Metabolism and Nutrition, vol. 1, European Association for Animal Production Publication no. 31. Les colloques de I'INRA, no. 16, pp. 69-96 [R. Pion, M. Arnal and D. Bonin, editors]. Paris: Institut National de la Recherche Agronomique.

Montgomery, G. M., Flux, D. S. \& Greenway, R. M. (1980). Tryptophan deficiency in pigs: changes in food intake and plasma levels of glucose, amino acids, insulin and growth hormone. Hormone and Metabolic Research 12, 304-309.

Pérez, J. M. \& Bourdon, D. (1982). Essai de replacement total du tourteau de soja dans le régime du porc en croissance: utilisation de pois supplémenté en tryptophane ou associé à un concentré de protéines du luzerne. (Total replacement of soybean meal in diets for growing pigs: use of peas supplemented with tryptophan or combined with an alfalfa protein concentrate.) Journées de la Recherche Porcine en France 14, 283-296.

Preedy, V. R. \& Garlick, P. J. (1985). The effect of glucagon administration on protein synthesis in skeletal muscles, heart and liver in vivo. Biochemical Journal 228, 575-581.

Reeds, P. J., Cadenhead, A., Fuller, M. F., Lobley, G. E. \& McDonald, J. D. (1980). Protein turnover in growing pigs. Effects of age and food intake. British Journal of Nutrition 43, 445-455.

Reeds, P. J., Fuller, M. F., Cadenhead, A., Lobley, G. E. \& McDonald, J. D. (1981). Effects of changes in the intakes of protein and non-protein energy on whole-body protein turnover in growing pigs. British Journal of Nutrition 45, 539-546.

Rothwell, N. J. \& Stock, M. J. (1978). A paradox in the control of energy intake in the rat. Nature 273, $146-147$.

Salter, D. N., Montgomery, A. I., Hudson, S., Quelch, D. B. \& Elliot, R. J. (1990). Lysine requirements and whole-body protein turnover in growing pigs. British Journal of Nutrition 63, 503-513.

SAS Institute Inc. (1988). SAS/STAT User's Guide, Release 6.03 ed. Cary, NC: SAS Institute Inc.

Sève, B. (1983). Tryptophan requirement of pigs weaned at 10 days of age. Interaction with the level of feeding. In Protein Metabolism and Nutrition, vol. 2, European Association for Animal Production Publication no. 31. Les colloques de l'INRA, no. 16, pp. 419-422 [R. Pion, M. Arnal and D. Bonin, editors]. Paris: Institut National de la Recherche Agronomique.

Sève, B. (1985). Physiological basis of nutrient supply to the piglets during the adapting and post-adapting stage of weaning. World Review of Animal Production 21, 7-14.

Sève, B., Aumaitre, A., Jaubert, P. \& Tord, P. (1978). Solubilisation des protéines de poisson, supplémentation en tryptophane et valeur alimentaire pour le porcelet. (Solubilization of fish protein, tryptophan supplementation and nutritive value for early weaned pigs.) Annales de Zootechnie 27, 423-437.

Sève, B., Reeds, P. J., Fuller, M. F., Cadenhead, A. \& Hay, S. M. (1986). Protein synthesis and retention in some tissues of the young pig as influenced by dietary protein intake after early weaning. Possible connection to the energy metabolism. Reproduction Nutrition Développement 26, 849-861.

Sidransky, H., Murty, C. N. \& Verney, E. (1984). Nutritional control of protein synthesis studies relating to tryptophan-induced stimulation of nucleocytoplasmic translocation of mRNA in rat liver. American Journal of Pathology 117, 298-309.

Sidransky, H., Verney, E. \& Sarma, D. S. R. (1971). Effect of tryptophan on polyribosomes and protein synthesis in liver. The American Journal of Clinical Nutrition 24, 779-785.

Tsiolakis, D. \& Marks, V. (1984). The differential effect of intragastric and intravenous tryptophan on plasma glucose, insulin, glucagon, GLI and GIP in the fasted rat. Hormone and Metabolic Research 16, 226-229.

Vesely, J. \& Cihak, A. (1970). Enhanced DNA-dependent RNA polymerase and RNA synthesis in rat liver nuclei after administration of L-tryptophan. Biochimica et Biophysica Acta 204, 614-616.

Wang, T. C. \& Fuller, M. F. (1989). The optimum dietary amino acid pattern for growing pigs. British Journal of Nutrition 62, 77-89. 